\title{
STRESS AND STRAIN FIELD OF PLATES WITH REINFORCED RECTANGULAR OPENINGS VARIOUSLY ORIENTATED RELATIVE TO THE DIRECTION OF THE TENSILE FORCE
}

\author{
${ }^{1}$ Institute of Technical Mechanics \\ of the National Academy of Sciences of Ukraine and the State Space Agency of Ukraine \\ 15 Leshko-Popel St., 49005, Dnipro, Ukraine \\ ${ }^{2}$ Oles Honchar Dnipro National University \\ 72 Gagarin Ave., 49010, Dnipro, Ukraine; e-mail: hart@ua.fm
}

\begin{abstract}
Computer models were developed for analyzing elastic rectangular plates with reinforced rectangular elongated openings acted upon by uniaxial tensile forces in the case of different orientations of the openings relative to the direction of the forces. The plate material and the reinforcing strip material are distinct from each other. Computer simulation was conducted using the finite-element method as part of a standard application package. The stress and strain field of a plate was studied as a function of the mechanical and geometric parameters of the plate and the reinforcements and the orientation of the openings (the angle the opening makes with the force direction). The stress concentration factor was studied as a function of the opening orientation and the ratio of the modulus of elasticity of the plate material to that of the reinforcement material (1/3 and 3). The simulation involved plates with openings making angles of $60^{\circ}, 45^{\circ}$, and $30^{\circ}$ with the load direction. The deformations of the plate and reinforcement materials laid in the elastic domain. It was shown that an appropriate choice of the geometric and stiffness parameters of a plate and reinforcements and of the opening orientation may significantly reduce the stress concentration in the plate. Patterns of the stress intensity distributions at plate sections passing along one of the opening sides and patterns of the stress concentration in the vicinity of the opening corner points are presented. The results obtained may be used in the solution of problems of optimization of thin-walled rectangular plates with elongated openings reinforced with strips at their ends at a low consumption of the reinforcing strip material.
\end{abstract}

Keywords reinforcement, plate, opening, stress, deformation, stress concentration factor, finite-element method.

1. Vainberg D. V. Stess Concentration in Plates near Openings and Round Corners (in Russian). Kyiv: Tekhnika, 1969. 220 pp.

2. Hart E. L., Panchenko S. V. Numerical analysis of the stress and strain field of a plate with a rectangular opening reinforced with triangular inserts (in Russian). Visnyk Dnipropetrovskoho Universytetu. Seriia Mekhanika. 2015. Issue 24. V. 2. Pp. $39-47$.

3. Hudramovych V. S. Effect of openings on the limiting states of components of metal thin-walled shell-andplate structures (in Russian). Vusnyk Dnipropetrovskogo Universytety. Seriia Mekhanika. 2014. Issue 18. V. 2.- Pp. 47-60.

4. Hudramovych V. S., Hart E. L., Panchenko S. V. Effect of strip inserts on the stress and strain field in a plate with an elongated rectangular opening (in Ukrainian). Teh. Meh. 2018. No. 1. Pp. 13 - 19.

5. Gudramovich V. S., Gart E. L., Strunin K. A. Simulation of straining the plate with elastic extended inclusions based on finite element method (in Russian). Teh. Meh. No. 2. Pp. $12-23$.

6. Guz A. N. Shall Calculation Methods. In 5 volumes. V. 1. Theory of Opening-Weakened Shells (in Russian). Kyiv : Naukova Dumka, 1980. 636 pp.

7. Zienkiewicz O. The Finite Element Method in Engineering (in Russian). Moscow: Mir, 1975. 541pp.

8. Lizin V. T., Pyatkin V. A. Design of Thin-Walled Structures (in Russian) Moscow: Mashinostroyeniye, 1994. $384 \mathrm{pp}$.

9. Mossakovskyi V. I., Kvasha O. M. Design and calculation of hatches that do not cause stress concentration in spherical shells (in Ukrainian). Prykladna Mekhanika. 1959. V. 5. No. 4. Pp. 371-378.

10. Oden J. T. Finite Elements of Nonlinear Continua (in Russian). Moscow : Mir, 1976. 464 pp.

11. Preobrazhensky I. N., Tsurpal I. A. Openings in Bearing Structures (in Russian). Moscow: Mashinostroyeniye, 1984. $112 \mathrm{pp}$. 